\title{
MOLECULAR METHODS FOR THE DETECTION OF NATURAL HYBRIDS IN STURGEON POPULATIONS
}

\author{
Alexandru BURCEA *, Iulia Elena FLORESCU *, Andreea DUDU *, \\ Sergiu Emil GEORGESCU * and Marieta COSTACHE *
}

* University of Bucharest, Faculty of Biology, Department of Biochemistry and Molecular Biology, Splaiul Independenţei 91-95, Bucharest, Romania, RO-050095, alexanburcea@gmail.com, iuliaflorescu_2006@yahoo.com,_tn_andreea@yahoo.com,_georgescu_se@yahoo.com, marietacostache@yahoo.com

DOI: 10.1515/trser-2015-0003

KEYWORDS: Danube, sturgeon populations, natural hybrids, molecular methods.

\begin{abstract}
Due to construction of the Iron Gates dams, the Lower Danube has suffered a decrease in sturgeon populations. The dams have decreased sturgeon habitat area, which in turn has caused an overlap of reproduction areas for all sturgeon species. The ease with which sturgeon species can create hybrid offsprings gave rise to an increase in the number of hybrid sturgeon species now found in the Lower Danube area. We propose a set of molecular methods for hybrid species using DNA markers represented by microsatellites and mitochondrial DNA. This identification data and methodology is important for use on sturgeon farms due to the need to correctly identify species of sturgeons. Using the proposed methodologies, it is possible to avoid identification errors that might appear when using only morphological criteria to idenfy sturgeons.

RÉSUMÉ: Méthodes moléculaires pour la détection des hybrides naturelles dans les populations d'esturgeons.

En raison de la construction de barrages aux Portes de Fer, le Danube inférieur a subi une diminution des populations d'esturgeon. La diminution de l'aire géographique a induit le chevauchement des sites de reproduction de toutes les espèces d'esturgeons. La facilité d'hybridation caractéristique de ces espèces a conduit à la situation actuelle qui est une augmentation du nombre d'hybrides d'esturgeons. Nous proposons plusieurs méthodes moléculaires pour l'identification des hybrides utilisant deux types de marqueurs d'ADN. Les données sont importantes pour les fermes d'esturgeons de part la nécessité d'une identification correcte des individus. Ainsi, il est possible de pallier les difficultés potentielles liées à une simple identification morphologique.

REZUMAT: Metode moleculare de detecție a hibrizilor naturali în populaṭii de sturioni. Datorită construcţiei barajelor de la Porţile de Fier, Dunărea Inferioară a suferit o descreştere a populaţiilor de sturioni. Restrângerea arealului a condus la suprapunerea zonelor de reproducere pentru toate speciile de sturioni. Acest fenomen, împreună cu uşurinţa hibridizării în cazul acestor specii, a condus la situaţia actuală, în care există o creştere a numărului hibrizilor naturali de sturioni. Propunem un set de metode moleculare pentru identificarea hibrizilor de sturioni, folosind două tipuri de markeri ADN. Datele obţinute sunt importante pentru fermele piscicole datorită necesităţii identificării corecte a indivizilor. Astfel, se pot evita eventualele dificultăţi apărute în identificarea indivizilor exclusiv pe baza criteriilor morfologice.
\end{abstract}




\section{INTRODUCTION}

Sturgeons are represented by the order Acipenseriformes, which contains 27 species divided in two families: Acipenseridae with 25 species, and Polyodontidae with two species (Zhang et al., 2013). This group of "living fossils" is undergoing a dramatic population decline in Eurasia, with fish populations currently at historically low levels (Ludwig, 2006; Ludwig et al., 2009). This decline is due to wrong harvesting, poaching and loss and degradation of habitat, specifically because of dams along rivers (Ludwig et al., 2009; Havelka et al., 2011).

Natural hybridization is one of the effects of habitat degradation and loss, especially in response to hindered migration to spawning areas that occurred in Romania after the construction of the Iron Gates dams. The dam installations, altered parts of the Lower Danube spawning habitats creating favorable conditions for two sturgeon species to overlap. This change in the ecological relationship between the two species left room for "habitat hybridization" (Tranah et al., 2004). Hybridization not only occurs in the wild under natural conditions but also in artificial breeding. Cases of both interspecific and intergeneric hybridization have been observed (Havelka et al., 2011), confirming the rate of this event, especially under the right circumstances.

Cross-breeding sturgeons have the ability to produce fully fertile hybrid offsprings (Havelka et al., 2011) more easily than other vertebrates. Due to possible crossbreeding that may have occurred, using a morphological description to identify sturgeon that may be hybrids is not enough to conclusively identify the sturgeon species. Because first-generation of hybrids are not morphologically intermediate to the genitor morphotypes (Tranah et al., 2004), coupled with the difficulty of identifying sturgeon hybrids in early growth stages such as fry and subadults (Zhang et al., 2013), there is a need for molecular hybrid identification and characterization.

One of the techniques for identifying hybrids and pure species sturgeons is PCR-RFLP (Polymerase Chain Reaction - Restriction Fragment Length Polymorphism). This technique is based on the amplification of the region tRNA ${ }^{\text {Glu }} /$ cytochrome b of 462 bp from the mitochondrial DNA and endonuclease restriction of this fragment. The restriction fragments observed on the electrophoresis gel are analyzed to show the maternal genitor species of an individual sturgeon. This technique is useful for confirming purespecies fish or finding out the maternal genitor of a hybrid because of the small intraspecific variations in sequence for the analyzed region (Wolf et al., 1999). The analysis is based on restriction of species-specific sites resulting in a species-specific band pattern with the use of a single universal primer pair (Ludwig, 2006).

Along with using PCR-RFLP as an identification technique, the DNA barcoding was also used for species identification, respectively for maternal genitor identification in the case of hybrids. The advantage of using DNA barcoding for sturgeon species is that it overcomes the possibility of incorrect identification due to using the phenotype only. Additionally, the DNA method is effective at any life-cycle stage and regardless of gender. From a molecular standpoint, DNA barcoding for the mitochondrial gene COI (Cytochrome Oxidase I) is good because of the haploid mode of inheritance, a lack of introns, and limited exposure for recombination (Hebert et al., 2003; Hubert et al., 2008). The DNA analysis is centered on genes because universal primers are very robust and because changes in the amino-acid sequence change slowly in respect to other mitochondrial genes (Hebert et al., 2003).

In the case of natural sturgeon hybrids, these two techniques lack precision due to the maternal inheritance of mitochondrial DNA (Havelka et al., 2011). For this reason we use nuclear microsatellites markers that are short-tandem repeats of two to nine nucleotides with a high-degree of length polymorphism. Because microsatellites are markers with great 
variability and due to the fact that they have co-dominant inheritance, unbiased by sex-specific differences (Nelson et al., 2013), microsattelites are used for various types of population studies, and in this case for hybrid identification and characterization. This is possible using the factorial correspondence analysis (FCA) test that shows the relationship of individual samples with respect to a microsatellite dataset of known individual samples.

\section{MATERIAL AND METHODS}

Molecular methods were tested using samples harvested without endangering the life of individual fish. Small fin fragments were collected from individual sturgeon captured in the Lower Danube and labeled as either pure species or hybrids based on their morphology. For total genomic DNA extraction from fin tissue we used a standard phenol/chloroform protocol modified from Taggart et al. (1992; 2004).

\section{PCR-RFLP}

The PCR reaction was made in a total volume of $25 \mu \mathrm{L}$ which contained: DNA template, 1X PCR Gold Buffer (AppliedBiosystems), $1.5 \mathrm{mM} \mathrm{MgCl}{ }_{2}, 200 \mu \mathrm{M}$ of each dNTP (AppliedBiosystems), $0.48 \mu \mathrm{M}$ of each primer (forward primer sequence: 5'AAAAACCACCGTTGTTATTCAACTA-3', reverse primer sequence 5'-GCCCCTCAG AATGATATTTGTCCTCA-3'), 1U AmpliTaq Gold DNA Polymerase (AppliedBiosystems), and nuclease-free water. The reaction mixes were amplified on GeneAmp 9700 PCR System (AppliedBiosystems) using the following cycling conditions: $95^{\circ} \mathrm{C}$ for 10 minutes, 40 cycles of $95^{\circ} \mathrm{C}$ for 30 seconds, $60^{\circ} \mathrm{C}$ for 45 seconds, $72^{\circ} \mathrm{C}$ for a minute and a final extension at $72^{\circ} \mathrm{C}$ for 10 minutes. For the enzymatic restriction we used a total volume of $20 \mu \mathrm{L}$ with: $2 \mu \mathrm{L}$ Reaction Buffer, $0.4 \mu \mathrm{L}$ Bovine Seric Albumine, $16.5 \mu \mathrm{L}$ PCR product and $1.1 \mu \mathrm{L}$ restriction enzyme: RsaI or SspI (Promega). The mix was incubated for three hours at $37^{\circ} \mathrm{C}$ and then visualized consequently electrophoresis in a $3 \%$ agarose gel alongside 50 bp DNA Step Ladder (Promega). Table 1 shows the enzymes we used in this study and the restriction fragment length attributed to the species of sturgeon still found in the Danube River.

Table 1: PCR-RFLP of the amplified cytb gene of four sturgeon species (Wolf et al., 1999).

\begin{tabular}{|c|l|l|l|l|}
\hline & Huso huso & Acipenser gueldenstaedtii & Acipenser stellatus & \multicolumn{1}{|c|}{ Acipenser ruthenus } \\
\hline \multirow{3}{*}{ RsaI } & $317 \mathrm{bp}$ & $317 \mathrm{bp}$ & $462 \mathrm{bp}$ & $341 \mathrm{bp}$ \\
\cline { 2 - 5 } & $112 \mathrm{bp}$ & $112 \mathrm{bp}$ & & $88 \mathrm{bp}$ \\
\cline { 2 - 5 } & $33 \mathrm{bp}$ & $33 \mathrm{bp}$ & & $33 \mathrm{bp}$ \\
\hline \multirow{3}{*}{$S s p \mathrm{I}$} & $277 \mathrm{bp}$ & $277 \mathrm{bp}$ & $462 \mathrm{bp}$ & $277 \mathrm{bp}$ \\
\cline { 2 - 5 } & $185 \mathrm{bp}$ & $185 \mathrm{bp}$ & & $185 \mathrm{bp}$ \\
\hline
\end{tabular}

DNA sequencing

For DNA barcoding we used a PCR mix with a total volume of $25 \mu \mathrm{L}$ containing $50 \mathrm{ng}$ of DNA template, 1X PCR Gold Buffer (AppliedBiosystems), $1.5 \mathrm{mM} \mathrm{MgCl} 2200 \mu \mathrm{M}$ of each dNTP (AppliedBiosystems), $0.4 \mu \mathrm{M}$ of each primer (forward: 5'TCAAGCCAGCCGCATAAC-3', reverse: 5'-CGCTATTCCCTATTTAGCTTCT-3'), 1U AmpliTaq Gold DNA Polymerase (AppliedBiosystems), nuclease-free water. The cycle conditions were as follows: $95^{\circ} \mathrm{C}$ for 10 minutes, then 35 cycles of $95^{\circ} \mathrm{C}$ for 30 seconds, different annealing temperatures for different hybrids for 30 seconds, $72^{\circ} \mathrm{C}$ for a minute and a final extension at $72^{\circ} \mathrm{C}$ for 10 minutes. The PCR products were visualized on $2 \%$ agarose gel and purified using Wizard SV Gel and PCR Clean-Up System (Promega). The sequencing of amplicons was done with BigDye Terminator v3.1 Cycle Sequencing Kit, the sequencing products were purified using BigDye XTerminator Purification Kit (AppliedBiosystems) and loaded on 3130 Genetic Analyzer (AppliedBiosystems) for capillary electrophoresis. We 
sequenced the forward and reverse strands for more accurate data; we edited the sequences using BioEdit Sequence Alignment Editor 7.1.9. (Hall, 1999) and then we aligned the resulting data with known sequences from various sturgeon species using the BOLD (Barcode of Life Data) system (Ratnasingham and Hebert, 2007) for identification.

\section{Microsatellite amplification}

For microsatellite genotyping, we selected a set of eight microsatellite markers presented in table 2, first isolated from North American sturgeon species and used for native species by cross-amplification. The reaction mixes were prepared in a total volume of $25 \mu \mathrm{L}$ with: $30 \mathrm{ng}$ of DNA template, 1X PCR Gold Buffer (AppliedBiosystems), $1.5 \mathrm{mM} \mathrm{MgCl} 2,200$ $\mu \mathrm{M}$ of each dNTP (AppliedBiosystems), $0.24 \mu \mathrm{M}$ of each primer with the forward primer fluorescently labeled, 1U AmpliTaq Gold DNA Polymerase (Applied Biosystems), nuclease free water. The reaction mixes were amplified on GeneAmp 9700 PCR System (AppliedBiosystems) using the following cycling conditions: $95^{\circ} \mathrm{C}$ for 10 minutes, then 35 cycles of $95^{\circ} \mathrm{C}$ for 30 seconds, specific annealing temperatures for the different primer pairs due to the different amplified microsatellite markers for 30 seconds, $72^{\circ} \mathrm{C}$ for a minute and a final extension at $72^{\circ} \mathrm{C}$ for 60 minutes. The amplified fragments were loaded with the GeneScan-500 LIZ Size Standard into ABI Prism 310 DNA Genetic Analyzer.

The statistical analysis of microsatellite genotype data was performed by FCA implemented in the program GENETIX (Belkhir et al., 2002).

Table 2: Microsatellite genotyping primer sequence.

\begin{tabular}{|c|c|l|}
\hline Locus & \multicolumn{1}{|c|}{ Species } & \multicolumn{1}{c|}{ Primer sequence from 5' to 3' } \\
\hline LS19 & Acipenser fulvescens & $\begin{array}{l}\text { F: CATCTTAGCCGTCTGTGGTAC } \\
\text { R: CAGGTCCCAATACAATGGC }\end{array}$ \\
\hline LS34 & Acipenser fulvescens & $\begin{array}{l}\text { F: TACATACCTTCTGCAACG } \\
\text { R: GATCCCTTCTGTTATCAAC }\end{array}$ \\
\hline LS39 & Acipenser fulvescens & $\begin{array}{l}\text { F: TTCTGAAGTTCACACATTG } \\
\text { R: ATGGAGCATTATTGGAAGG }\end{array}$ \\
\hline LS54 & Acipenser fulvescens & $\begin{array}{l}\text { F: CTCTAGTCTTTGTTGATTACAG } \\
\text { R: CAAAGGACTTGAAACTAGG }\end{array}$ \\
\hline Aox27 & Acipenser oxyrhinchus & $\begin{array}{l}\text { F: AATAACAATAACGGCAGAACCT } \\
\text { R: TGTGTTGCTCAAGACAGTATGA }\end{array}$ \\
\hline AoxD234 & Acipenser oxyrhinchus & $\begin{array}{l}\text { F: AACTGGCTTTGTGATTGATCC } \\
\text { R: TGAAGCAAAGGGTATTATTTGAG }\end{array}$ \\
\hline AnacC4 & Acipenser naccari & $\begin{array}{l}\text { F: TCAGCTACAGGGTTCTGGG } \\
\text { R: GTTGTTACTCATTGGAACTC }\end{array}$ \\
\hline Acipenser naccari & $\begin{array}{l}\text { F: AAATTTCCATTGGGGTGT } \\
\text { R: CTTCGTTTTGAGAACCCG }\end{array}$ \\
\hline
\end{tabular}

RESULTS AND DISCUSSION

The FCA statistical interpretation, based on the eight nuclear microsatellite loci, (Fig. 1) shows three clusters of pure-species individuals surrounding and the analyzed hybrids (marked as 203 and 204) which show up between these pure-species clusters. The position occupied by hybrid 204 indicates that this is a hybrid between Acipenser ruthenus and Acipenser gueldenstaedtii. The maternal genitor species identified by mitochondrial DNA marker analysis is represented by an individual belonging to Acipenser ruthenus species, while the paternal genitor is from Acipenser gueldenstaedtii. 
In the case of hybrid 203, the genitors are represented by Acipenser gueldenstaedtii as paternal genitor and Huso huso as maternal genitor, this last one being confirmed by mitochondrial DNA marker analysis (Figs. 2, 3 and 4).

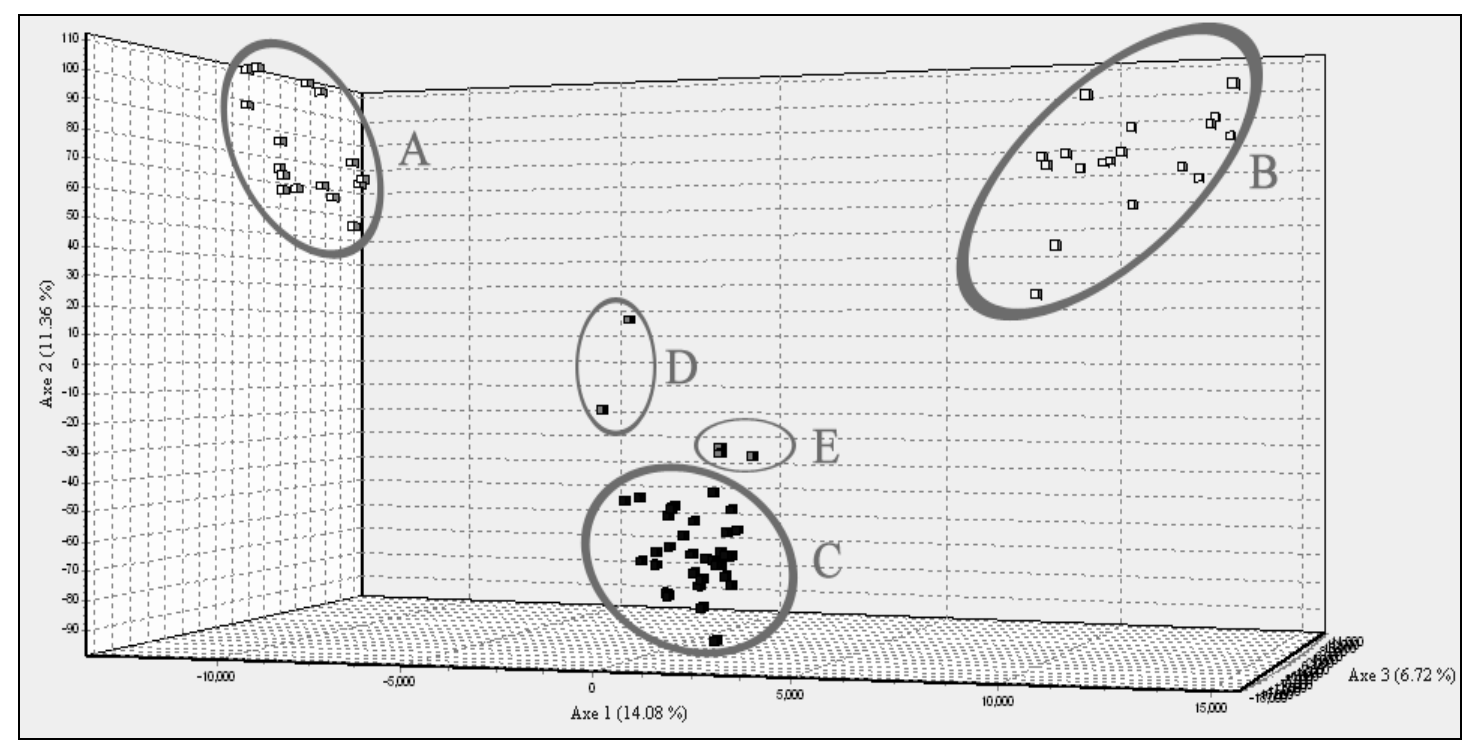

Figure 1: GENETIX - FCA hybrid analysis; A - Acipenser ruthenus; B - Huso huso;

C - Acipenser gueldenstaedtii; D - hybrid 204; E - hybrid 203.

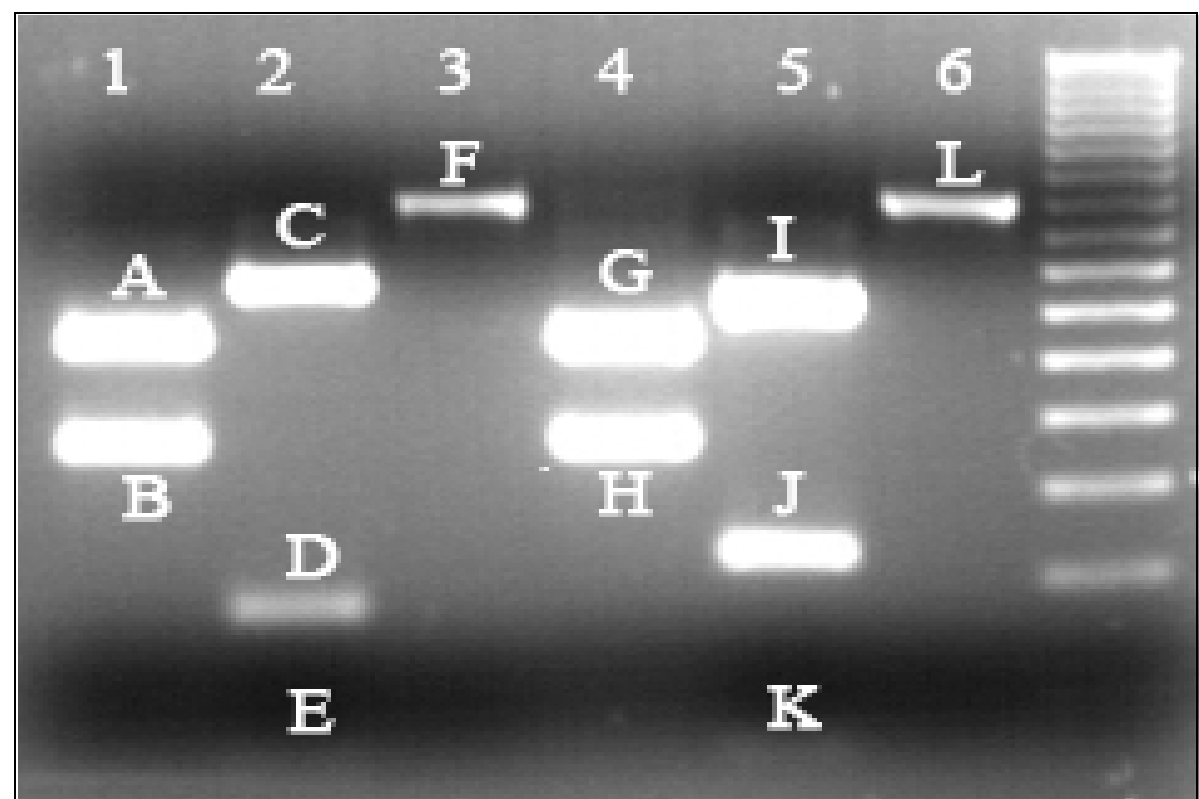

Figure 2: PCR-RFLP electrophoresis gel with 50 bp DNA Step Ladder;

1, 2 , 3 - hybrid 204; 4, 5, 6 - hybrid 203; F, L - uncut fragments, 462 bp; A, B - Ssp. I restriction fragments, $277 \mathrm{bp}$ and $185 \mathrm{bp}$; C, D, E - RsaI restriction fragments, $341 \mathrm{bp}, 88 \mathrm{bp}$ and 33 bp; G, H - SspI restriction fragments, 277 bp and 185 bp;

I, J, K - RsaI restriction fragments, 317 bp, 112 bp and 33 bp. 
Using maternal genitor identification by PCR-RFLP analysis, the electrophoretic gel (Fig. 2) shows that for hybrid 204 the SspI digested fragments, $277 \mathrm{bp}$ and $185 \mathrm{bp}$, are common between $H$. huso, A. gueldenstaedtii and A. ruthenus, but because of the RsaI digested fragment length the result is pinpointed to A. ruthenus with $341 \mathrm{bp}, 88 \mathrm{bp}, 33 \mathrm{bp}$ fragments. In case of hybrid 203 the SspI digested fragments show the same patterns as for hybrid 204 but the RsaI band pattern, indicates as maternal genitor species to $H$. huso or A. gueldenstaedtii.

The PCR-RFLP analysis showed that hybrid 204 has maternal lineage from $A$. ruthenus yet hybrid 203 has a lineage from $H$. huso or A. gueldenstaedtii. The BOLD system was used to confirm the lineage of hybrid 204 and to clarify the origin of hybrid 203. This BOLD system identification showed that the hybrid 204 barcode sequence (Fig. 3) is a 100\% match with $A$. ruthenus. Results for hybrid 203 (Fig. 4) showed a 99.9\% similarity to the $H$. huso barcode sequence, thereby excluding thus the possibility of A. gueldenstaedtii as a paternal genitor as was previously highlighted by PCR-RFLP band pattern. For both hybrids the top five matches are the species to which they are assigned, raising confidence in results.

Using PCR-RFLP and BOLD system sequence alignment we conclude that for hybrid 204 the maternal genitor is $A$. ruthenus while $H$. huso is the maternal genitor for hybrid 203.

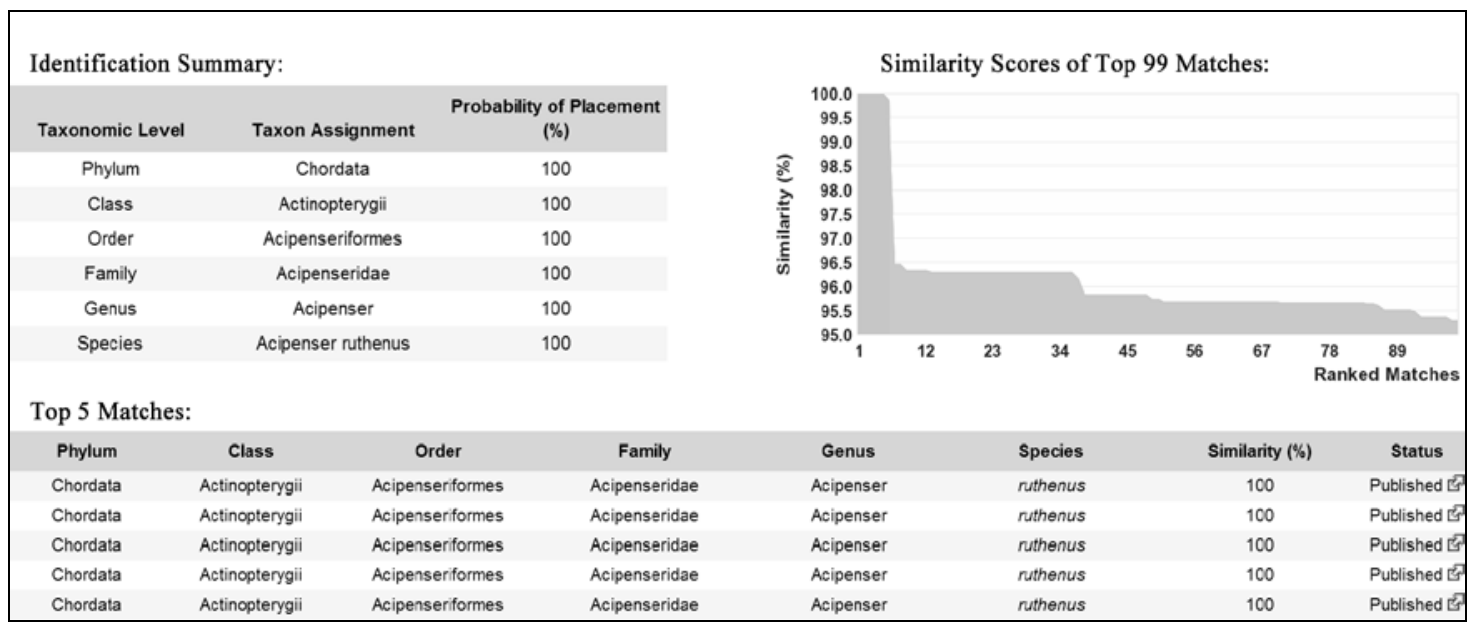

Figure 3: Hybrid 204, BOLD system sequence alignment.

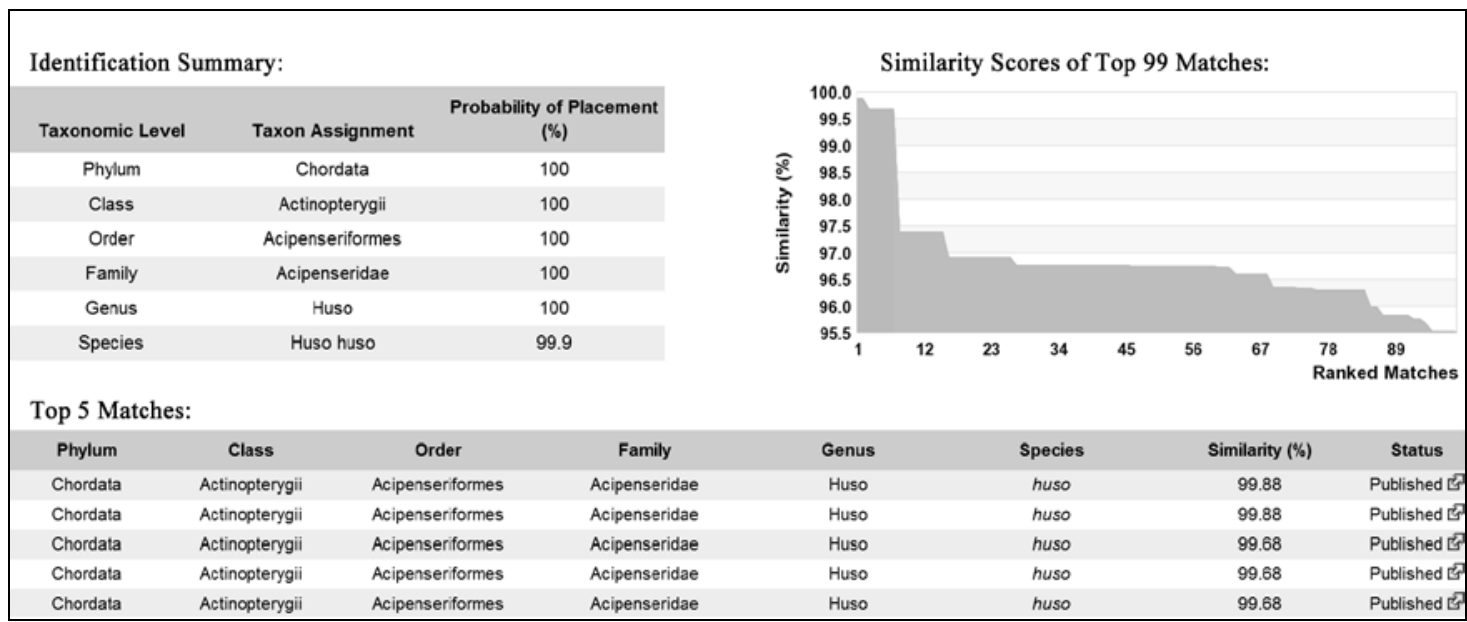

Figure 4: Hybrid 203, BOLD system sequence alignment. 


\section{CONCLUSIONS}

Based on our analysis we conclude that the methods used here are particularly effective in hybrid characterization, yielding information not only about the identification of a sturgeon hybrid but also about the maternal and paternal ancestry of the individual sturgeon in question.

With the current difficulty in morphological characterization of natural sturgeon hybrids because of their unknown genitors, we propose the methods shown above provide the most reliable methodologies for identifying hybrids and the pure-stock sturgeon species. The specific application of these methodologies at various fish farms would allow people to identify and then avoid using hybrids in reproduction and repopulation programs that might lead to the alteration of the native populations.

\section{ACKNOWLEDGEMENTS}

This work was supported by the PN-II-PT-PCCA Project 116/2012 “Genetic evaluation and monitoring of molecular and biotechnological factors that influence productive performance of Danube sturgeon species breeding in intensive recirculating systems”. 


\section{REFERENCES}

1. Belkhir K., Borsa P., Goudet J., Chikhi L. and Bonhomme F., 2002 - Genetix, logiciel sous WindowsTM pour la génétique des populations, Laboratoire Génome et populations, CNRS UPR 9060, Université de Montpellier II, Montpellier, France. (in French)

2. Havelka M., Kašpar V., Hulák M. and Flajšhans M., 2011 - Sturgeon genetics and cytogenetics: a review related to ploidy levels and interspecific hybridization, Folia Zoologica, 60, 2, 93-103.

3. Hebert P. D. N., Cywinska A., Ball S. L. and deWaard J. R., 2003 - Biological identifications through DNA barcodes, Proceedings of the Royal Society B: Biological Sciences, 270, 313-321.

4. Hubert N., Hanner R., Holm E., Mandrak N., Taylor E., Burridge M., Watkinson D., Dumont P., Curry A., Bentzen P., Zhang J., April J. and Bernatchez L., 2008 - Identifying Canadian Freshwater Fishes through DNA Barcodes, PLoS ONE, 3, 6, e2490.

5. Ludwig A., 2006 - A sturgeon view on conservation genetics, European Journal of Wildlife Research, 52, 3-8.

6. Ludwig A., Lippold S., Debus L. and Reinartz R., 2009 - First evidence of hybridization between endangered sterlets (Acipenser ruthenus) and exotic Siberian sturgeons (Acipenser baerii) in the Danube River, Biological Invasions, 11, 753-760.

7. Nelson T. C., Doukakis P., Lindley S. T., Schreier A. D., Hightower J. E., Hildebrand L. R., Whitlock R. E. and Webb M. A. H., 2013 - Research Tools to Investigate Movements, Migrations, and Life History of Sturgeons (Acipenseridae), with an Emphasis on MarineOriented Populations, PLoS ONE 8, 8, e71552.

8. Ratnasingham S. and Hebert P. D. N., 2007 - BOLD: The Barcode of Life Data System (www.barcodinglife.org), Molecular Ecology Notes, 7, 355-364.

9. Taggart J. B., Hynes R. A., Prodohl P. A. and Ferguson A., 1992 - A simplified protocol for routine total DNA isolation from salmonid fishes, Journal of Fish Biology, 40, 963-965.

10. Taggart G., Campton D. E. and May B., 2004 - Genetic Evidence for Hybridization of Pallid and Shovelnose Sturgeon, Journal of Heredity 95, 6, 474-480.

11. Wolf C., Hubner P. and Luthy J., 1999 - Differentiation of sturgeon species by PCR-RFLP, Food Research International, 32, 699-705.

12. Zhang X., Wu W., Li L., Ma X. and Chen J., 2013 - Genetic variation and relationships of seven sturgeon species and ten interspecific hybrids, Genetics Selection Evolution, 45, 21. 